\title{
Influence of ruminal methane on digesta retention and digestive physiology in non-lactating dairy cattle
}

\author{
Marie T. Dittmann ${ }^{1,2,3}$, Kirsty J. Hammond ${ }^{3} \dagger$, Paul Kirton $^{3}$, David J. Humphries ${ }^{3}$, Les A. Crompton ${ }^{3}$, \\ Sylvia Ortmann ${ }^{4}$, Tom H. Misselbrook ${ }^{5}$, Karl-Heinz Südekum ${ }^{6}$, Angela Schwarm², Michael Kreuzer ${ }^{2}$, \\ Christopher K. Reynolds ${ }^{3}$ and Marcus Clauss ${ }^{1 *}$ \\ ${ }^{1}$ Clinic for Zoo Animals, Exotic Pets and Wildlife, Vetsuisse Faculty, University of Zurich, Winterthurerstr. 260, 8057 Zurich, \\ Switzerland \\ ${ }^{2}$ ETH Zurich, Institute of Agricultural Sciences, Universitätsstr. 2, 8092 Zurich, Switzerland \\ ${ }^{3}$ Sustainable Agriculture and Food Systems Research Division, Centre for Dairy Research, School of Agriculture, Policy and \\ Development, University of Reading, PO Box 237, Earley Gate, Reading RG6 6AR, UK \\ ${ }^{4}$ Leibniz Institute for Zoo and Wildlife Research (IZW), Alfred-Kowalke-Str. 17, 10315 Berlin, Germany \\ ${ }^{5}$ Rothamsted Research, North Wyke, Okehampton, Devon EX2O 2SB, UK \\ ${ }^{6}$ Institute of Animal Science, University of Bonn, Endenicher Allee 15, 53115 Bonn, Germany
}

(Submitted 22 January 2016 - Final revision received 7 June 2016 - Accepted 22 June 2016 - First published online 25 July 2016)

\begin{abstract}
Enteric methane $\left(\mathrm{CH}_{4}\right)$ production is a side-effect of herbivore digestion, but it is unknown whether $\mathrm{CH}_{4}$ itself influences digestive physiology . We investigated the effect of adding $\mathrm{CH}_{4}$ to, or reducing it in, the reticulorumen (RR) in a $4 \times 4$ Latin square experiment with rumen-fistulated, non-lactating cows, with four treatments: (i) control, (ii) insufflation of $\mathrm{CH}_{4}\left(\mathrm{iCH}_{4}\right.$ ), (iii) $\mathrm{N}$ via rumen fistula, (iv) reduction of $\mathrm{CH}_{4}$ via administration of bromochloromethane (BCM). DM intake (DMI), apparent total tract digestibility, digesta mean retention times (MRT), rumen motility and chewing activity, spot breath $\mathrm{CH}_{4}$ emission $\left(\mathrm{CH}_{4}\right.$ exhal, litre/kg DMI) as well as $\mathrm{CH}_{4}$ dissolved in rumen fluid $\left(\mathrm{CH} \mathrm{RRf}_{4}, \mu \mathrm{g} / \mathrm{ml}\right)$ were measured. Data were analysed using mixed models, including treatment (or, alternatively, $\mathrm{CH}_{4} \mathrm{exhal}_{\mathrm{O}} \mathrm{CH}_{4} \mathrm{RRf}$ ) and $\mathrm{DMI}$ relative to body mass ${ }^{0.85}$ (rDMI) as covariates. rDMI was the lowest on the $\mathrm{BCM}$ treatment. $\mathrm{CH}_{4}$ exhal was highest for $\mathrm{iCH}_{4}$ and lowest for $\mathrm{BCM}$ treatments, whereas only BCM affected (reduced) $\mathrm{CH}_{4} \mathrm{RRf}$. After adjusting for rDMI, $\mathrm{CH}_{4} \mathrm{RRf}$ had a negative association with MRT in the gastrointestinal tract but not in the RR, and negative associations with fibre digestibility and measures of rumination activity. Adjusting for rDMI, $\mathrm{CH}_{4}$ exhal had additionally a negative association with particle MRT in the RR and a positive association with rumen motility. Thus, higher rumen levels of $\mathrm{CH}_{4}\left(\mathrm{CH}_{4}\right.$ exhal or $\left.\mathrm{CH}_{4} \mathrm{RRf}\right)$ were associated with shorter MRT and increased motility. These findings are tentatively interpreted as a feedback mechanism in the ruminant digestive tract that aims at mitigating $\mathrm{CH}_{4}$ losses by shortening $\mathrm{MRT}$ at higher $\mathrm{CH}_{4}$.
\end{abstract}

\section{Key words: Digestion: Passage rate: Mean retention time: Motility: Rumination activity}

The production of enteric methane $\left(\mathrm{CH}_{4}\right)$ is considered an undesired (but partially unavoidable) side-effect of the fermentation of plant material by micro-organisms present in the gastrointestinal tract (GIT) of herbivores. It represents a loss of energy to the animal $(2-12 \%)^{(1)}$, and contributes substantially to the greenhouse effect ${ }^{(2)}$. In ruminants, the production of $\mathrm{CH}_{4}$ is the last step of the fermentation process and is carried out by methanogenic Archaea (methanogens). These methanogens utilise $\mathrm{H}_{2}$ as an energy source to reduce carbon dioxide to $\mathrm{CH}_{4}^{(3)}$. This is the predominant way of $\mathrm{H}_{2}$ utilisation, despite the presence of alternative, more energy-efficient $\mathrm{H}_{2}$ sinks in the ruminant forestomach, such as acetogens ${ }^{(4)}$ or propionic acid production $^{(5)}$.

Previous studies have suggested that a reduced residence time of ingested plant material in the digestive tract (measured as mean retention time (MRT)) is associated with lower $\mathrm{CH}_{4}$ emission $\left(\mathrm{CH}_{4}\right.$ exhal) in ruminants ${ }^{(6-10)}$, ratites ${ }^{(11)}$ and nonruminant foregut fermenters ${ }^{(12,13)}$. This has also been reflected in models for the prediction of ruminant enteric $\mathrm{CH}_{4}$ exhal that included MRT (or passage rate) as a predictive factor ${ }^{(14,15)}$.

Abbreviations: $\mathrm{BCM}$, bromochloromethane; $\mathrm{BM}$, body mass; $\mathrm{CH}_{4}$ exhal, methane emission; $\mathrm{CH}_{4} \mathrm{RRf}$, methane in rumen fluid; $\mathrm{CP}$, crude protein; DMI, DM intake; GIT, gastrointestinal tract; $\mathrm{iCH}_{4}$, insufflation of methane; $\mathrm{iN}_{2}$, insufflations of nitrogen; MRT, mean retention time; MRT solute $\mathrm{RR}_{\text {, }} \mathrm{MRT}$ of solutes in the reticulorumen; NDF, neutral detergent fibre; rDMI, relative DM intake; RR; reticulorumen.

* Corresponding author: M. Clauss, fax +41 4463 58901, email mclauss@vetclinics.uzh.ch

$\dagger$ Present address: AgResearch Grasslands Research Centre, Tennent Drive, Private Bag 11008, Palmerston North 4442, New Zealand. 
In addition, a lower $\mathrm{CH}_{4}$ exhal was measured in steers (Bos taurus domesticus) after the placement of weights in their reticulum, which decreased MRT ${ }^{(16)}$. It has been shown that increased MRT of digesta is associated with increased $\mathrm{CH}_{4}$ exhal in humans ${ }^{(17,18)}$. The $\mathrm{CH}_{4}$ breath test has been used as a diagnostic aid in the investigation of 'irritable bowel syndrome', where patients with increased exhaled $\mathrm{CH}_{4}$ are ascribed to the 'constipation type' of the syndrome ${ }^{(19,20)}$; however, see Di Stefano et al. ${ }^{(21)}$.

Although these studies suggest a causative relationship - that is, a reduction in $\mathrm{CH}_{4}$ exhal due to a reduced MRT - the question whether the presence of $\mathrm{CH}_{4}$ itself influences digestive physiology, particularly factors affecting MRT such as gut motility, has received less attention. The presence of $\mathrm{CH}_{4}$ in the GIT was found to modulate peristalsis of the small intestine, inducing augmented contractile activity in the guinea pig (Cavia porcellus) ileum in vitro ${ }^{(22,23)}$. It also apparently delayed intestinal transit of digesta through the jejunum of fistulated dogs (Canis lupus familiaris) ${ }^{(22)}$. However, added $\mathrm{CH}_{4}$ had no effect on the guinea pig colon in vitro ${ }^{(23)}$. The overall interpretation in these studies is that $\mathrm{CH}_{4}$ in the GIT slows down intestinal transit. In humans, treatment with antibiotics decreased the concentration of $\mathrm{CH}_{4}$ in the breath (putatively due to eliminating methanogens) and alleviated obstipationtype irritable bowel syndrome exhibited in patients who produced $\mathrm{CH}_{4}$ before antibiotic administration ${ }^{(24)}$. In ruminants, $\mathrm{CH}_{4}$ exhal was reduced in sheep (Ovis aries) fed nitrate (an alternative $\mathrm{H}_{2}$-acceptor), and there was an associated reduction of fluid retention in the reticulorumen $(\mathrm{RR})^{(25)}$. In contrast, no changes were apparent in rumen retention times when reducing $\mathrm{CH}_{4}$ exhal in cattle using chloroform ${ }^{(26)}$.

On the basis of all these reports, our objective was to determine the effects of $\mathrm{CH}_{4}$ insufflation $\left(\mathrm{iCH}_{4}\right)$ or $\mathrm{CH}_{4}$ inhibition on digesta kinetics in non-lactating dairy cows. We hypothesised that the level of $\mathrm{CH}_{4}$ within the ruminant GIT has an effect on gut peristalsis, motility, digesta propulsion and consequently MRT in ruminants. It was expected that an increased presence of $\mathrm{CH}_{4}$ would delay passage from both the RR and the GIT. Such a relationship could indicate an evolutionary scenario in which the presence of methanogens (and therefore $\mathrm{CH}_{4}$ ) in the ruminant digestive tract increases MRT, and hence contributes to the well-documented physiological adaptations of ruminants that enhance their ability to utilise a fibrous diet by giving microbes more time to degrade fibrous nutrients.

\section{Methods}

\section{Experimental design}

This experiment was conducted at the University of Reading's Centre for Dairy Research (CEDAR), UK. All procedures were licenced and monitored by the UK Home Office Animals (Scientific Procedures) Act 1986. In total, four rumen-fistulated, non-lactating, non-pregnant Holstein dairy cows were used in a $4 \times 4$ Latin square design experiment with 28 -d periods, commencing with $7 \mathrm{~d}$ of individual tie-stall housing for adaptation to treatments ( $d$ 1-7), a 7 -d measurement period (d 8-14), followed by a 14-d recovery period (d 15-28) with free-stall housing. The four treatments were (i) control (C), ruminal insufflation (mean 295 (sD 82) litre/d) of either (ii) $\mathrm{CH}_{4}$ gas $\left(\mathrm{iCH}_{4}\right)$ or (iii) $\mathrm{N}_{2}$ gas $\left(\mathrm{iN}_{2}\right.$ ) via the fistula and (iv) reduction of $\mathrm{CH}_{4}$ production via ruminal administration of bromochloromethane (BCM). Measurements during d 8-14 included individual DM intake (DMI), apparent total tract digestibility of feed components, digesta MRT, rumen $\mathrm{pH}$, rumen motility, rumination and chewing activity, breath $\mathrm{CH}_{4}$ exhal (determined three times daily using a GreenFeed unit (C-Lock)) and $\mathrm{CH}_{4}$ concentration in rumen fluid $\left(\mathrm{CH}_{4} \mathrm{RRf}\right)$.

\section{Animals and housing}

Animals aged 6-13 years, with an initial mean body mass (BM) of 712 (SD 81) kg, were surgically fitted with a rumen cannula (type \#1C, 100-mm centre diameter; Bar Diamond Inc.) during a previous lactation. Cannulae plugs were fitted with airtight ports that allowed the placement of infusion lines or motility sensors into the rumen.

During adaptation and measurement periods ( $\mathrm{d}$ 1-14), cows were kept in individual tie stalls and DMI was measured. Cows were bedded on rubber mats with a layer of wood shavings that was replenished twice daily. During the recovery period (d 15-28), cows were group housed in a cubicle yard with straw bedding. On $\mathrm{d} 1 \mathrm{of}$ the recovery period, approximately $20 \mathrm{~kg}$ of the RR contents from the animal that had received the BCM treatment was removed via the fistula and replaced with a corresponding amount of RR content from the other three animals that had not received the BCM treatment (approximately $7 \mathrm{~kg}$ from each cow) to minimise carry-over effects of BCM.

Cows were fed the same diet for the entire experimental period consisting of chopped timothy (Phleum pratense L.) hay from an external supplier, a limited amount of a commercial pellet (Super Rearer 18 Nuts; BOCM Pauls Ltd) ${ }^{(27)}$ at 863 (sD 6) g $\mathrm{DM} / \mathrm{cow}$ per $\mathrm{d}$ and daily $100 \mathrm{~g} / \mathrm{cow}$ of a mineral mixture (CW FA super dry cow; Countrywide Farmers); see Table 1 for nutrient composition of the ingredients and diets. The low crude protein (CP) content of the hay had not been intended but was confirmed in analyses of multiple sample replicates. Because of this low CP content, the ingested diets had CP levels of $54-56 \mathrm{~g} / \mathrm{kg}$ DM (Table 1), which is below the recommendations for dry cows ${ }^{(28)}$. We had intended to restrict cows to intakes of $1.2 \times$ metabolisable energy (ME) requirements for maintenance ${ }^{(29)}$ estimated on the basis of the supplier's analysis of the hay, in order to minimise excessive weight gain and feed refusals. However, because of the large variation in intake displayed from the very beginning (with refusals ranging from 0.3 to $1.6 \mathrm{~kg} \mathrm{DM}$ of hay/cow per $\mathrm{d}$, possibly due to the low $\mathrm{CP}$ content of the hay), hay was offered ad libitum from the onset of the study. During the adaptation and measurement periods, cows were fed three times daily at 09.00, 15.00 and 21.00 hours, and during the recovery periods cows were fed once daily.

\section{Insufflation treatments}

Gaseous $\mathrm{CH}_{4}$ (treatment ii: $\mathrm{iCH}_{4}$ ) was insufflated continuously from an external bottle into the ventral rumen via the fistula. As a control for gaseous $\mathrm{CH}_{4}$, gaseous $\mathrm{N}_{2}$ (treatment iii: $\mathrm{iN}_{2}$ ) 
Table 1. Mean nutrient composition ( $\mathrm{g} / \mathrm{kg} \mathrm{DM})$ of the diets offered to the cows over the four experimental periods and of the respective consumed diets per treatment

\begin{tabular}{lccrrrrr}
\hline & & & \multicolumn{3}{c}{ Diets consumed in treatment } \\
\cline { 3 - 7 } Nutrients & Chopped timothy hay & Pelleted concentrate & Control & $\mathrm{iCH}_{4}$ & $\mathrm{iN}_{2}$ & \multirow{2}{*}{$\mathrm{BCM}$} & SEM \\
\hline Organic matter & 969 & 922 & 964 & 963 & 964 & 963 & 0.2 \\
Crude protein & 39 & 182 & 54 & 55 & 54 & 56 & 0.7 \\
Neutral detergent fibre & 592 & 359 & 568 & 566 & 568 & 563 & 1.2 \\
Acid detergent fibre & 340 & 139 & 319 & 317 & 319 & 316 & $2 \cdot 1$ \\
\hline
\end{tabular}

$\mathrm{iCH}_{4}$, methane insufflation; $\mathrm{i}_{2}$, nitrogen insufflation; $\mathrm{BCM}$ bromochloromethane.

was insufflated using the same set-up as for $\mathrm{iCH}_{4}$. Both $\mathrm{CH}_{4}$ and $\mathrm{N}_{2}$ were insufflated at an average rate of 295 (SD 82) litre/d (205 (sD 57) $\mathrm{ml} / \mathrm{min} ; 276$ (sD 31) litre/d for $\mathrm{iCH}_{4}$ and 313 (sD 37) litre/d for $\mathrm{iN}_{2}$ ), which was intended to double the amount of enteric $\mathrm{CH}_{4}$ gas produced from non-lactating dairy cows ${ }^{(30)}$.

To control insufflation rates and to ensure that they were similar for $\mathrm{iCH}_{4}$ and $\mathrm{iN}_{2}$ treatments, $\mathrm{CH}_{4}$ and $\mathrm{N}_{2}$ gas cylinders (both British Oxygen Company; 99.5\% purity) were placed on electronic balances (GFK 150H; Adam Equipment). From the cylinders, gases flowed via flexible gas-tight tubing (PFA Flexible Tubing) to peristaltic pumps (LA 1 P; Omicron) and then through flow metres (GEC Marconi). From the peristaltic pumps, $\mathrm{CH}_{4}$ and $\mathrm{N}_{2}$ were insufflated into the rumen via tubes leading through the fistula. A chromium steel weight of about $100 \mathrm{~g}$ was fitted to the end of each insufflation tube for placement in the ventral rumen. The insufflation tubes used ended in a perforated coil covered with a nylon bag to prevent clogging. This solution was chosen on the basis of an in vitro pilot study during which aquarium bubble stones had been tested. The stones had already partly dissolved after $24 \mathrm{~h}$ in the rumen fluid, and digesta particles had clogged most holes, leading to bubbles rising from a single opening. All tubing and fittings were airtight and regularly checked for leaks. On the basis of bottle weight changes, masses of $\mathrm{CH}_{4}$ and $\mathrm{N}_{2}$ administered were recorded at least twice daily.

\section{Methane-reduction treatment}

To reduce $\mathrm{CH}_{4}$ exhal, a dose of $0.45 \mathrm{~g}$ BCM/ $100 \mathrm{~kg} \mathrm{BM}$ was administered directly into the rumen twice daily via the fistula (i.e., a total daily dose of $0.9 \mathrm{~g} / 100 \mathrm{~kg})^{(31)}$, at 08.00 and at 17.00 hours (treatment iv: BCM). The inhibitor compound was prepared by entrapping BCM in an $\alpha$-cyclodextrin matrix ${ }^{(32)}$, which was dissolved in a syringe containing $120 \mathrm{ml}$ of warm water immediately before administration into the rumen via a silicone tube through the fistula. Before this study, the efficacy of the BCM compound was confirmed in vitro by the Hohenheim gas test $^{(33)}$ (data not shown).

\section{Body mass, feed intake and whole-tract digestibility}

Cows were weighed at the start and end of each treatment period. Feeds offered and refused as well as faeces were collected and weighed daily for $5 \mathrm{~d}$ from $\mathrm{d} 8$ to 12 of each measurement period. Pooled composites from each individual cow for each measurement period were collected and frozen at $-20^{\circ} \mathrm{C}$ before being thawed and sub-sampled for further analyses and determination of whole-tract digestibility. Total daily collection, sampling and processing of faeces were performed using previously described methods ${ }^{(34)}$.

\section{Digesta kinetics and rumen $\mathrm{pH}$}

To measure MRT of particles and fluid, the following markers were used: three different-sized particle markers based on fibre from grass hay mordanted with $\mathrm{Cr}(<2 \mathrm{~mm})$, La $(5 \mathrm{~mm})$ and Ce $(8 \mathrm{~mm})$ as particle markers and the water-soluble Co-EDTA ${ }^{(35,36)}$. For $3 \mathrm{~d}$ before administration of markers, 1 faecal sample/d and a single rumen fluid sample on the last of these days were collected to determine baseline marker concentrations for each animal. Markers were administered into the RR at 08.00 hours on $\mathrm{d} 8$ via the fistula, where each cow received $7 \mathrm{~g}$ Co-EDTA and $70 \mathrm{~g}$ of each particle marker, soaked in warm water. After marker administration, a sample of faeces (at least $10 \%$ of the total amount defaecated in the interval) was collected every $1-3 \mathrm{~h}$ on $\mathrm{d} 8$, every $4 \mathrm{~h}$ on $\mathrm{d} 9$, every $6 \mathrm{~h}$ on $\mathrm{d} 10$, every $8 \mathrm{~h}$ on $\mathrm{d} 11-13$ and every $12 \mathrm{~h}$ on $\mathrm{d} 14$. Faecal samples were oven-dried immediately at $60^{\circ} \mathrm{C}$ for $48 \mathrm{~h}$. In addition, rumen fluid was sampled every $1-3 \mathrm{~h}$ for $24 \mathrm{~h}$ after marker administration to determine the decline in Co concentration in the rumen. Rumen fluid samples $(40 \mathrm{ml})$ were collected from the ventral sac via aspiration through a coarse filtered tube inserted vertically and approximately $40 \mathrm{~cm}$ into the rumen mat directly below the rumen fistula. Each rumen fluid sample was mixed gently, and $\mathrm{pH}$ was measured immediately (pH meter: HI2210; Hanna Instruments) before it was stored frozen at $-20^{\circ} \mathrm{C}$ for analysis of Co concentration.

\section{Rumen motility}

Contractions of the RR were measured by a system developed by the Physiological Institute of the University of Veterinary Medicine Hannover (Hannover, Germany). Nitrile rubber balloons of approximately $7-\mathrm{cm}$ diameter were attached to a pressure sensor via flexible tubing and placed in the dorsal part of the rumen. Rumen contractions were recorded continuously for approximately $8 \mathrm{~h}$ on $\mathrm{d} 4$ or 5 of the measurement period. Balloons were placed in the RR only for the duration of these measurements. Data from the motility sensors were analysed using software developed by Itin + Hoch $\mathrm{GmbH}$ (available from the corresponding author) for the frequency of contractions, the length of individual contractions as well as the interval between contractions. Primary and secondary contractions could not be differentiated by this method. 


\section{Chewing activity}

Jaw movement of the cows was recorded from d 8 to 13 using noseband sensors (RumiWatchSystem; Itin + Hoch $\mathrm{GmbH})^{(37)}$. Data from the noseband sensors were analysed using RumiWatch Converter software (Itin + Hoch $\mathrm{GmbH}$ ) to determine time spent ruminating and eating, the number of regurgitated boli per day as well as the chewing frequency during eating and rumination.

\section{Methane levels in breath and rumen fluid}

$\mathrm{CH}_{4}$ exhal in the breath of cows (exhaled $\mathrm{CH}_{4}$ ) was measured three times daily at approximately 09.30, 13.00 and 16.30 hours from d 10 to 12 using a GreenFeed unit ${ }^{(38)}$. The GreenFeed unit was mounted on wheels, which allowed positioning in the feed manger of each cow, where it was left in place long enough to allow each cow to consume a proportion of the daily allotment of pellets and obtain a $\mathrm{CH}_{4}$ measurement. The average rate of $\mathrm{CH}_{4}$ exhal $(\mathrm{g} / \mathrm{min})$ from the three daily readings was converted into an emission rate per day, and the results are expressed as estimated daily $\mathrm{CH}_{4}$ production (litre/d) and yield (litre/kg DMI).

Ruminal $\mathrm{CH}_{4}$ concentrations were determined from rumen fluid samples collected once daily (at 11.00 hours) from d 9-11 ${ }^{(39)}$. Samples of centrifuged rumen fluid $(2 \mathrm{ml})$ were maintained in anaerobic conditions and added to an equal volume of lactic acid (13 $\mathrm{M})$ in an evacuated headspace crimp top vial $(22 \mathrm{ml}$; Perkin Elmer) and thoroughly mixed. The vials were returned to atmospheric pressure with $\mathrm{N}_{2}$, and the headspace was analysed for $\mathrm{CH}_{4}$ concentration using $\mathrm{GC}$ (Clarus 500; Perkin Elmer), fitted with a megabore capillary Elite PLOT $\mathrm{Q}$ column (Perkin Elmer) and a flame ionisation detector set at $350^{\circ} \mathrm{C}$. A bracketed calibration using five gas standards was used with each batch of samples, and calibration samples of known concentration were included at regular intervals within each sample run. The concentration of $\mathrm{CH}_{4}$ liberated from samples was proportional and linear over the range of $0.5-3.0 \mathrm{ml}$ of added rumen fluid.

\section{Sample analyses}

Pooled composite samples for digestibility measurements of feed offered, refused feed and faeces were analysed ${ }^{(40)}$ for DM and total ash (Association of Official Analytical Chemists (AOAC) no. 942.05), CP (AOAC no. 977.02), neutral detergent fibre (NDF, AOAC no. 2002.04 using $\alpha$-amylase) and acid detergent fibre (ADF, AOAC no. 973.18). All fibre values were corrected for residual ash content, and all analyses were performed in duplicate.

Concentrations of $\mathrm{Co}, \mathrm{Cr}, \mathrm{La}$ and $\mathrm{Ce}$ in faecal and rumen fluid samples were analysed $^{(41)}$ after wet ashing with $4 \mathrm{ml}$ nitric acid and $2 \mathrm{ml}$ hydrogen peroxide in a microwave oven. The temperature was increased over $15 \mathrm{~min}$ to $170^{\circ} \mathrm{C}$ and over $20 \mathrm{~min}$ to $200^{\circ} \mathrm{C}$, and then held at $200^{\circ} \mathrm{C}$ for $5 \mathrm{~min}$. The wave-length was $12.25 \mathrm{~cm}$, and the frequency was $2.45 \mathrm{GHz}$. Concentrations of $\mathrm{Co}, \mathrm{Cr}$, La and $\mathrm{Ce}$ in the samples were determined using an inductively coupled plasma optical emission spectrometer (model Optima 8000; Perkin Elmer). Co concentration from the rumen fluid sampled through the fistula was determined as described above, but without wet ashing.

\section{Digesta kinetics calculations}

RR liquid volume and MRT of solutes in the RR (MRT solute $_{\text {RR) }}$ were calculated from marker concentrations in rumen samples. All other MRT measures (for both GIT and RR) were obtained from faecal marker concentrations, including a second additional measure for $\mathrm{MRT}_{\text {solute }} \mathrm{RR}$. The RR liquid volume was estimated by dividing the amount of Co-marker administered by the slope of the regression of ln-transformed Co concentrations over time ${ }^{(42)}$. The MRT of digesta phases represented by the four markers (solutes, small, intermediate and large particles) were determined by a multi-compartmental model, using equation 8 of Dhanoa et al. ${ }^{(43)}$ for curve fitting and equation 12 of that publication for MRT calculation. Values were corrected for individual baseline concentrations (taken before the marker application). Values $<1 \%$ of the maximum concentration of a marker in the excretion curve were set to 0 to avoid an artificial increase in MRT by infinite excretion curves due to variation in baseline concentrations ${ }^{(44)}$.

\section{Statistical analysis}

The relative DMI (rDMI) was expressed per $\mathrm{kg} \mathrm{BM}^{0 \cdot 85(45,46)}$. As rDMI typically shows a good correlation with MRT measures ${ }^{(47)}$, this measure is particularly suitable to control for the effect of feed intake across different-sized individuals. Data were averaged for each cow and treatment, and the effect of treatments was determined via mixed-model procedures that included treatment and treatment period (periods 1-4) as fixed factors, cow as a random factor and rDMI as a covariate. All statistical tests were carried out in R 3.0.2 $2^{(48)}$ using the function lme from the package nlme, followed by the function drop 1 to determine significances of the fixed factors by stepwise exclusion. As treatments had different effects on $\mathrm{CH}_{4}$ exhal yield and $\mathrm{CH}_{4} \mathrm{RRf}$, the same models (with rDMI as covariate) were additionally applied with exhaled $\mathrm{CH}_{4}$ yield (litre/kg DMI) or $\mathrm{CH}_{4}$ in rumen fluid $(\mu \mathrm{g} / \mathrm{ml})$ as covariates instead of treatment as a fixed factor. In addition, means of measures were compared between treatments using paired $t$ tests with Holm-Bonferroni adjustment for multiple testing. Significance levels were set to $P<0.05$.

\section{Results}

\section{Effects on intake, body mass change and} methane measurements

Absolute DMI varied from $7 \cdot 1$ to $8 \cdot 4 \mathrm{~kg} / \mathrm{d}$. There was an influence of treatment on $\mathrm{rDMI}(P=0.024)$, which was lowest for cows on the BCM treatment and highest for the control treatment (Table 2). Exhaled $\mathrm{CH}_{4}$ was affected by treatment $(P<0.001)$ (Table 2). Compared with the control, exhaled $\mathrm{CH}_{4}$ yield (litre/kg DMI) was reduced on average by $82 \%$ with $\mathrm{BCM}$ treatment $(P<0 \cdot 001)$, increased on average by $78 \%$ with $\mathrm{iCH}_{4}$ treatment $(P<0.001)$ and unaffected by $\mathrm{iN}_{2}$ treatment $(P=0 \cdot 96) . \mathrm{CH}_{4}$ in rumen fluid was similar across treatments, except for BCM treatment, which was lower than all other treatments $(P<0.001)$ (Table 2), representing a reduction of $99 \%$. 
Table 2. Treatment means and effect of treatments (Trx) and relative feed DM intake (rDMI) on methane $\left(\mathrm{CH}_{4}\right)$ and measurements of digestive physiology

\begin{tabular}{|c|c|c|c|c|c|c|c|}
\hline \multirow[b]{2}{*}{ Measurements } & \multicolumn{4}{|c|}{$\operatorname{Tr} x$} & \multirow[b]{2}{*}{ SEM } & \multicolumn{2}{|c|}{$P$} \\
\hline & Control & $\mathrm{iCH}_{4}$ & $\mathrm{iN}_{2}$ & $\mathrm{BCM}$ & & Trx & rDMI \\
\hline Initial BM (kg) & 715 & 722 & 731 & 707 & $17 \cdot 4$ & - & - \\
\hline $\mathrm{DMI}(\mathrm{kg} / \mathrm{d})$ & 8.4 & $7 \cdot 7$ & $8 \cdot 2$ & $7 \cdot 1$ & 0.28 & - & - \\
\hline rDMI (g/kg ${ }^{0.85}$ per d) & 31.5 & $29 \cdot 0$ & $30 \cdot 2$ & $27 \cdot 2$ & $1 \cdot 21$ & 0.024 & - \\
\hline $\mathrm{BM}$ change $(\mathrm{kg})$ & -19 & -35 & -35 & 2 & $5 \cdot 5$ & 0.005 & 0.208 \\
\hline \multicolumn{8}{|l|}{$\mathrm{CH}_{4}$ exhaled in breath } \\
\hline Litre/d & $275^{a}$ & $438^{b}$ & $250^{\mathrm{a}}$ & $42^{c}$ & $38 \cdot 1$ & $<0.001$ & 0.102 \\
\hline Litre/kg BM & $0.38^{a}$ & $0.61^{b}$ & $0.34^{a}$ & $0.06^{c}$ & 0.05 & $<0.001$ & 0.002 \\
\hline Litre/kg DMI & $32 \cdot 5^{\mathrm{a}}$ & $57 \cdot 8^{b}$ & $30 \cdot 5^{\mathrm{a}}$ & $6 \cdot 00^{c}$ & 4.90 & $<0.001$ & 0.033 \\
\hline \multicolumn{8}{|l|}{$\mathrm{CH}_{4}$ dissolved in rumen fluid } \\
\hline$\mu \mathrm{g} / \mathrm{ml}$ & $3.76^{a}$ & $3.40^{\mathrm{a}}$ & $3.48^{a}$ & $0.03^{b}$ & 0.41 & $<0.001$ & 0.700 \\
\hline \multicolumn{8}{|l|}{ Mean retention time $(\mathrm{h})$} \\
\hline Solute GIT & $32 \cdot 3$ & 35.6 & $35 \cdot 2$ & 40.5 & $1 \cdot 28$ & 0.004 & 0.170 \\
\hline $2 \mathrm{~mm}$ GIT & 73.0 & $76 \cdot 8$ & 73.6 & 93.6 & $4 \cdot 23$ & 0.008 & $<0.001$ \\
\hline $5 \mathrm{~mm}$ GIT & $83 \cdot 1$ & $86 \cdot 0$ & $87 \cdot 9$ & $103 \cdot 8$ & 3.98 & 0.010 & 0.002 \\
\hline $8 \mathrm{~mm}$ GIT & 89.6 & 91.0 & 95.4 & $110 \cdot 1$ & $4 \cdot 26$ & 0.045 & 0.003 \\
\hline Solute RR (from faeces) & $17 \cdot 6$ & $18 \cdot 7$ & $19 \cdot 3$ & $20 \cdot 9$ & 0.94 & 0.407 & 0.835 \\
\hline Solute RR (from rumen fluid) & $10 \cdot 9$ & $12 \cdot 2$ & 11.4 & $12 \cdot 7$ & 0.53 & 0.888 & 0.016 \\
\hline $2 \mathrm{~mm}$ RR & $44 \cdot 1$ & $42 \cdot 7$ & $42 \cdot 4$ & $56 \cdot 0$ & 2.92 & 0.158 & 0.079 \\
\hline $5 \mathrm{~mm} \mathrm{RR}$ & $48 \cdot 2$ & $48 \cdot 0$ & $51 \cdot 0$ & 61.5 & 2.92 & 0.255 & 0.046 \\
\hline $8 \mathrm{~mm} \mathrm{RR}$ & $54 \cdot 3$ & $52 \cdot 5$ & $58 \cdot 9$ & $67 \cdot 6$ & $3 \cdot 29$ & 0.329 & 0.052 \\
\hline \multicolumn{8}{|l|}{ Apparent digestibility (\%) } \\
\hline DM & $61 \cdot 1$ & 61.5 & 61.6 & $63 \cdot 1$ & 0.67 & 0.234 & 0.571 \\
\hline Organic matter & $62 \cdot 6$ & $63 \cdot 1$ & $63 \cdot 1$ & 64.5 & 0.69 & 0.243 & 0.493 \\
\hline Crude protein & $34 \cdot 6$ & $35 \cdot 0$ & 34.4 & $40 \cdot 8$ & $1 \cdot 22$ & 0.047 & 0.518 \\
\hline Neutral detergent fibre & $46 \cdot 8$ & $47 \cdot 3$ & $47 \cdot 7$ & $50 \cdot 6$ & $1 \cdot 16$ & 0.010 & 0.076 \\
\hline Acid detergent fibre & $42 \cdot 4$ & 43.6 & $41 \cdot 2$ & $46 \cdot 6$ & 1.55 & 0.135 & 0.367 \\
\hline Rumen fluid $\mathrm{pH}$ & $6 \cdot 81$ & 6.84 & $6 \cdot 81$ & 6.89 & 0.031 & 0.740 & 0.038 \\
\hline Faeces DM (g/kg DM) & 175 & 178 & 174 & 186 & $30 \cdot 6$ & $0 \cdot 164$ & 0.912 \\
\hline RR liquid volume (litres) & $84 \cdot 6$ & 93.0 & $86 \cdot 2$ & $102 \cdot 2$ & 3.96 & 0.440 & 0.053 \\
\hline \multicolumn{8}{|l|}{ Chewing activity and rumination } \\
\hline Time ruminating $(\mathrm{min} / \mathrm{h})$ & $25 \cdot 5^{a}$ & $22 \cdot 7^{\mathrm{a}, \mathrm{b}}$ & $23 \cdot 7^{\mathrm{a}, \mathrm{b}}$ & $27 \cdot 3^{b}$ & 0.74 & 0.002 & 0.449 \\
\hline Time eating $(\mathrm{min} / \mathrm{h})$ & $7 \cdot 0$ & $7 \cdot 3$ & $7 \cdot 8$ & $6 \cdot 6$ & 0.50 & 0.375 & 0.162 \\
\hline Ruminating chews (per h) & 1636 & 1472 & 1546 & 1729 & 51.8 & 0.025 & 0.645 \\
\hline Eating chews (per h) & 476 & 495 & 555 & 436 & $40 \cdot 8$ & $0 \cdot 137$ & 0.214 \\
\hline Boli (per h) & $23 \cdot 3$ & 21.4 & $22 \cdot 5$ & $25 \cdot 7$ & 0.93 & 0.006 & 0.889 \\
\hline Chewing rate RUM (per min) & $67 \cdot 0$ & $64 \cdot 1$ & $65 \cdot 3$ & $69 \cdot 6$ & 0.98 & 0.041 & 0.487 \\
\hline Chewing rate RUM (per bolus) & $58 \cdot 2$ & $54 \cdot 3$ & $56 \cdot 0$ & $61 \cdot 3$ & 0.96 & 0.004 & 0.157 \\
\hline \multicolumn{8}{|l|}{ Rumen motility } \\
\hline Contractions (per min) & 1.54 & $1 \cdot 83$ & 1.58 & 1.41 & 0.07 & 0.010 & 0.037 \\
\hline Interval between contractions (s) & $40 \cdot 4$ & 33.4 & 39.9 & $45 \cdot 3$ & 2.08 & 0.038 & 0.035 \\
\hline Contraction length (s) & 5.03 & 4.98 & 4.92 & 4.94 & 0.24 & 0.989 & 0.969 \\
\hline
\end{tabular}

$\mathrm{iCH}_{4}$, methane insufflation; $\mathrm{N}_{2}$, nitrogen insufflation; BM, body mass; BCM, bromochloromethane; DMI, DM intake; GIT, gastrointestinal tract; RR, reticulorumen; RUM, during rumination.

${ }_{\mathrm{a}, \mathrm{b}, \mathrm{c} U n l i k e}$ superscript letters were significantly different (paired $t$ test with Holm-Bonferroni adjustment; $P<0.05$ ) between treatments

\section{Effects on digesta kinetics}

Both in the GIT and the RR, the MRT increased from the solute to the small, to the intermediate and to the large particle marker $(P<0.001$ in all cases $)$. Treatment had an influence on both solute and particle MRT in the GIT $(P \leq 0 \cdot 045)$, but not in the RR $(P \geq 0 \cdot 16)$ (as determined either directly via rumen samples or indirectly via faeces) (Table 2). For $\mathrm{MRT}_{2 \mathrm{~mm}} \mathrm{GIT}$ and MRT $_{5 \mathrm{~mm}}$ GIT, there were trends for an increased MRT for the BCM treatment when compared with the control in pairwise comparisons $\left(\mathrm{MRT}_{2 \mathrm{~mm}}\right.$ GIT: unadjusted $P=0.022$; $\mathrm{MRT}_{5 \mathrm{~mm}} \mathrm{GIT}$ : unadjusted $P=0.073$ ). There was a negative influence of $\mathrm{rDMI}$ on particle MRT measurements in the GIT $(P \leq 0.003)$ and RR $\left(P \leq 0.052\right.$, with only a trend in $\mathrm{MRT}_{2 \mathrm{~mm}} \mathrm{RR}$ ) (Table 2). The $\mathrm{MRT}_{\text {solute }} \mathrm{GIT}$ and $\mathrm{MRT}_{\text {solute }} \mathrm{RR}$ measured via faeces were not influenced by rDMI, whereas the $\mathrm{MRT}_{\text {solute }} \mathrm{RR}$ measured via rumen samples was negatively influenced by rDMI
( $P=0.016)$, indicating a divergence between the two values (Table 2).

When exhaled $\mathrm{CH}_{4}$ yield (litre/kg DMI) was used as the covariate instead of treatment, there was a tendency for a negative effect on all MRT measures $(P \leq 0 \cdot 059)$, including those for the RR, except for $\mathrm{MRT}_{\text {solute }} \mathrm{RR}$ (from both faeces and rumen, $P \geq 0.33$ ) (Table 3 ). Using exhaled $\mathrm{CH}_{4}$ yield as the covariate, there was a negative influence of rDMI on all MRT measurements determined from faecal samples $(P \leq 0 \cdot 029)$ but not for $\mathrm{MRT}_{\text {solute }} \mathrm{RR}$ determined directly from rumen samples $(P=0 \cdot 29)$.

When $\mathrm{CH}_{4}$ in rumen fluid $(\mu \mathrm{g} / \mathrm{ml})$ was used as the covariate, there was a negative influence on all MRT measures in the GIT $(P \leq 0.052)$, but no effect in the RR $(P \geq 0 \cdot 10)$. Relative DMI tended to have a negative effect on all MRT measures $(P \leq 0.095)$ except for $\mathrm{MRT}_{\text {solute }} \mathrm{RR}$ (as determined indirectly from the faeces, $P=0 \cdot 82$ ) (Table 3 ). 
Table 3. Relation of methane $\left(\mathrm{CH}_{4}\right)$ levels exhaled in breath and dissolved in rumen fluid to measures of digestive physiology in mixed models that included methane and the relative feed DM intake (rDMI) as covariates

\begin{tabular}{|c|c|c|c|c|c|c|c|c|}
\hline \multirow[b]{3}{*}{ Fixed factors } & \multicolumn{4}{|c|}{ Exhaled $\mathrm{CH}_{4}$ in breath } & \multicolumn{4}{|c|}{$\mathrm{CH}_{4}$ dissolved in rumen fluid } \\
\hline & \multicolumn{2}{|c|}{ Litre/kg DMI } & \multicolumn{2}{|c|}{ rDMI } & \multicolumn{2}{|c|}{$\mu \mathrm{g} / \mathrm{ml}$} & \multicolumn{2}{|c|}{ rDMI } \\
\hline & $P$ & Slope & $P$ & Slope & $P$ & Slope & $P$ & Slope \\
\hline rDMI $\left(g / k^{0.85}\right.$ per d) & 0.355 & $<0.001$ & - & - & 0.006 & 0.001 & - & - \\
\hline \multicolumn{9}{|l|}{ Mean retention time $(h)$} \\
\hline Solute GIT & 0.053 & -0.068 & 0.004 & $-744 \cdot 6$ & 0.001 & $-1 \cdot 387$ & 0.083 & -408.0 \\
\hline $2 \mathrm{~mm}$ GIT & 0.003 & -0.231 & $<0.001$ & $-2990 \cdot 6$ & 0.007 & $-3 \cdot 012$ & 0.002 & $-2322 \cdot 8$ \\
\hline $5 \mathrm{~mm}$ GIT & $<0.001$ & -0.268 & $<0.001$ & -2623.8 & 0.012 & -2.908 & 0.005 & $-2116 \cdot 9$ \\
\hline $8 \mathrm{~mm}$ GIT & 0.003 & -0.287 & $<0.001$ & $-2657 \cdot 2$ & 0.052 & $-2 \cdot 721$ & 0.010 & $-2267 \cdot 6$ \\
\hline Solute RR (from faeces) & 0.334 & -0.031 & 0.294 & -223.9 & 0.103 & -0.682 & 0.816 & -54.5 \\
\hline Solute RR (from rumen fluid) & 0.671 & 0.007 & 0.003 & $-287 \cdot 6$ & 0.532 & -0.136 & 0.011 & -268.7 \\
\hline $2 \mathrm{~mm} R R$ & 0.027 & -0.220 & 0.019 & -1429.5 & 0.127 & -2.041 & 0.095 & $-1215 \cdot 3$ \\
\hline $5 \mathrm{~mm} R R$ & 0.034 & -0.222 & 0.013 & $-1483 \cdot 1$ & 0.170 & -1.851 & 0.044 & $-1348 \cdot 2$ \\
\hline $8 \mathrm{~mm}$ RR & 0.059 & -0.251 & 0.029 & $-1459 \cdot 3$ & 0.274 & -1.824 & 0.054 & $-1341 \cdot 7$ \\
\hline \multicolumn{9}{|l|}{ Apparent digestibility (\%) } \\
\hline DM & 0.129 & -0.032 & 0.636 & -61.5 & 0.058 & -0.529 & 0.727 & 57.9 \\
\hline Organic matter & 0.158 & -0.028 & 0.655 & $-58 \cdot 1$ & 0.075 & -0.472 & 0.702 & 60.8 \\
\hline Crude protein & 0.016 & $-0 \cdot 108$ & 0.090 & -357.7 & 0.006 & -1.538 & 0.572 & $-129 \cdot 8$ \\
\hline Neutral detergent fibre & 0.028 & -0.067 & 0.907 & $25 \cdot 3$ & $<0.001$ & $-1 \cdot 289$ & 0.070 & $364 \cdot 2$ \\
\hline Acid detergent fibre & 0.233 & -0.063 & 0.948 & $-23 \cdot 1$ & 0.052 & $-1 \cdot 291$ & 0.494 & $219 \cdot 4$ \\
\hline Rumen fluid $\mathrm{pH}$ & 0.297 & $<0.001$ & 0.007 & $-16 \cdot 0$ & 0.640 & -0.005 & 0.033 & $-15 \cdot 1$ \\
\hline Faeces DM (g/kg DM) & 0.171 & -0.014 & 0.293 & $-92 \cdot 0$ & 0.013 & -0.328 & 0.987 & $-4 \cdot 2$ \\
\hline RR liquid volume (litres) & 0.620 & -0.070 & 0.007 & -2543.9 & 0.081 & -2.758 & 0.043 & -1814.5 \\
\hline \multicolumn{9}{|l|}{ Chewing activity and rumination } \\
\hline Time ruminating $(\mathrm{min} / \mathrm{h})$ & 0.002 & -0.086 & 0.809 & 36.8 & 0.013 & $-1 \cdot 199$ & 0.234 & 418.5 \\
\hline Time eating $(\mathrm{min} / \mathrm{h})$ & 0.490 & 0.009 & 0.167 & $137 \cdot 1$ & 0.867 & -0.031 & 0.177 & $162 \cdot 7$ \\
\hline Ruminating chews (per $h$ ) & 0.006 & -4.989 & 0.717 & $3656 \cdot 2$ & 0.042 & $-57 \cdot 499$ & 0.367 & $16250 \cdot 8$ \\
\hline Eating chews (per h) & 0.402 & 0.804 & 0.137 & $11585 \cdot 5$ & 0.836 & 2.739 & 0.221 & $11901 \cdot 4$ \\
\hline Boli (per h) & 0.001 & -0.079 & 0.670 & $-74 \cdot 1$ & 0.004 & $-1 \cdot 119$ & 0.229 & 266.5 \\
\hline Chewing rate RUM (per min) & 0.011 & -0.097 & 0.389 & $-182 \cdot 2$ & 0.014 & -1.246 & 0.884 & 40.9 \\
\hline Chewing rate RUM (per bolus) & 0.001 & -0.123 & 0.111 & $-234 \cdot 8$ & 0.023 & $-1 \cdot 140$ & 0.390 & $-137 \cdot 6$ \\
\hline Head low $(\mathrm{min} / \mathrm{h})$ & 0.001 & 0.071 & $<0.001$ & $-642 \cdot 5$ & 0.030 & 0.647 & $<0.001$ & -713.5 \\
\hline \multicolumn{9}{|l|}{ Rumen motility } \\
\hline Contractions (per min) & 0.003 & 0.007 & 0.060 & $21 \cdot 6$ & 0.082 & 0.058 & 0.175 & 16.9 \\
\hline Interval between contractions (s) & 0.008 & -0.203 & 0.039 & $-732 \cdot 3$ & 0.071 & -1.794 & 0.144 & -585.5 \\
\hline Contraction length (s) & 0.753 & 0.002 & 0.982 & -0.806 & 0.567 & 0.056 & 0.795 & -15.9 \\
\hline
\end{tabular}

DMI, dry matter intake; GIT, gastrointestinal tract; RR, reticulorumen; RUM, during rumination.

\section{Effects on apparent whole-tract digestibility}

Treatment had no effect on the apparent digestibility of DM, organic matter (OM) and ADF (Table 2). Treatment had an effect on the digestibility of CP and NDF $(P<0.05)$, which were both highest for the BCM treatment.

Using exhaled $\mathrm{CH}_{4}$ yield (litres/kg DMI) as the covariate, there was no effect on the digestibility of DM, OM or ADF, but a negative effect on the digestibility of $\mathrm{CP}$ and NDF was found $(P \leq 0.028)$ (Table 3$)$. Using $\mathrm{CH}_{4}$ in rumen fluid $(\mu \mathrm{g} / \mathrm{ml})$ as the covariate also yielded a negative effect on $\mathrm{CP}$ and NDF digestibility $(P \leq 0.006)$, and negative trends were observed on the digestibility of $\mathrm{DM}, \mathrm{OM}$ and $\mathrm{ADF}(P \leq 0.075)$ (Table 3$)$. Relative DMI tended to negatively influence NDF digestibility $(P<0 \cdot 070)$.

\section{Effects on rumen fluid $\mathrm{pH}, \mathrm{DM}$ content of the faeces and reticuloruminal volume}

Treatment did not show an influence on rumen $\mathrm{pH}$, the DM content of the faeces and the liquid volume in the RR $(P \geq 0 \cdot 16)$ (Table 2$)$; rDMI negatively affected rumen $\mathrm{pH}(P=0 \cdot 038)$.
Exhaled $\mathrm{CH}_{4}$ yield (litre/kg DMI) as the covariate had no significant influence on rumen $\mathrm{pH}$, the $\mathrm{DM}$ content of the faeces and liquid volume in the RR (Table 3); rDMI negatively influenced rumen $\mathrm{pH}$ and liquid volume in the $\mathrm{RR}(P=0 \cdot 007)$.

$\mathrm{CH}_{4}$ in rumen fluid $(\mu \mathrm{g} / \mathrm{ml})$ as the covariate negatively affected the DM content of the faeces $(P=0.013)$ and tended to negatively affect the liquid volume in the $\mathrm{RR}(P=0.081)$ (Table 3); rDMI negatively affected rumen $\mathrm{pH}$ and liquid volume in the RR $(P \leq 0.043)$.

\section{Effects on chewing, rumination and rumen motility}

Treatment affected all measures of rumination $(P \leq 0 \cdot 041)$, but had no influence on the animals' eating behaviour (time spent eating and number of chews during eating; $P \geq 0 \cdot 13$ ) (Table 2). Animals spent more time ruminating on BCM, compared with the control $(P=0.002)$. Treatment affected the number of regurgitated boli per hour $(P=0.006)$ and the number of chews per bolus $(P=0.004)$, which were both highest on BCM (Table 2).

Applying either exhaled $\mathrm{CH}_{4}$ yield (litre/kg DMI) or $\mathrm{CH}_{4}$ in rumen fluid $(\mu \mathrm{g} / \mathrm{ml})$ as covariates had a negative influence on 
all rumination measures $(P \leq 0 \cdot 042)$, but no effect on eating measures $(P \geq 0 \cdot 40)$ (Table 3$)$.

For rumen motility measurements, both treatment and rDMI affected the number of contractions and the interval between contractions $(P \leq 0.038)$, with the fewest contractions and the longest interval between contractions on the BCM treatment, but there was no effect on the length of contractions $(P \geq 0 \cdot 97)$. Exhaled $\mathrm{CH}_{4}$ yield (litre/kg DMI) as the covariate was positively related to the number of contractions $(P=0.003)$ and negatively related to the interval between contractions $(P=0.008)$; rDMI influenced the latter measurement negatively $(P=0 \cdot 039) . \mathrm{CH}_{4}$ in rumen fluid $(\mu \mathrm{g} / \mathrm{ml})$ as the covariate tended to positively affect the number of contractions $(P=0.082)$ and negatively affect the interval between contractions $(P=0 \cdot 071)$, with no influence of rDMI (Table 3).

\section{Discussion}

The present study investigated the effects of $\mathrm{iCH}_{4}$ or rumen $\mathrm{CH}_{4}$ inhibition on the digestive physiology of non-lactating dairy cows, including measurements of intake, digesta retention times, total tract digestibility, chewing activity and rumination, and rumen motility. When comparing treatments, a reduction in $\mathrm{CH}_{4}$ exhal was accompanied by a decrease in DMI, an increase in MRT in the GIT, a reduction in rumen motility and an increase in NDF digestibility, whereas $\mathrm{iCH}_{4}$ or $\mathrm{iN}_{2}$ did not result in a clear pattern. As a change in DMI alone could have explained the patterns observed on reduced $\mathrm{CH}_{4}$ exhal, variation in DMI had to be accounted for in the statistical analyses. When assessing effects as responses not to treatment but to either the concentration of $\mathrm{CH}_{4}$ in rumen fluid or exhaled $\mathrm{CH}_{4}$ yield and including $\mathrm{rDMI}$ as a covariable in the analyses, a systematic negative association of increased $\mathrm{CH}_{4}$ with MRT was indicated. These results must be considered with caution because of the unexpectedly low CP content of the hay provided. Although differences between the four MRT markers were as expected, with increasing MRT from solute to small, intermediate and large particles ${ }^{(49,50)}$, the absolute difference between the small particle marker (mordanted with $\mathrm{Cr}$ ) and the two larger particle markers (marked with La and Ce) was possibly underestimated, because for a given particle size $\mathrm{Cr}$ mordants are typically retained longer than lanthanide markers ${ }^{(51)}$

\section{Intra-ruminal gas insufflation}

Insufflation of gas into the rumen does not necessarily affect the concentration of gas dissolved in the rumen fluid, as evident, for example, from the absence of increased concentrations of dissolved ammonia in the ventral rumen fluid after insufflation of ammonia gas ${ }^{(52)}$. In order to affect the concentration of a gas dissolved in fluid, mechanical treatment such as shaking is required ${ }^{(53)}$. Correspondingly, $\mathrm{iCH}_{4}$ in the present study did not increase the measured concentration of $\mathrm{CH}_{4} \mathrm{RRf}$. Similarly, a very low effect of insufflating $\mathrm{H}_{2}$ on $\mathrm{CH}_{4}$ production had been interpreted as a consequence of an assumed incomplete dissolution of the gas in rumen fluid ${ }^{(54)}$. The increase in estimated daily $\mathrm{CH}_{4}$ exhal via exhaled air, based on 3 short-term measurements/d, over $3 \mathrm{~d}$, accounted for $60 \%$ of the $\mathrm{iCH}_{4}$ rate.
Although this recovery rate was lower than that reported for the GreenFeed system when compared with other methods of measuring $\mathrm{CH}_{4}^{(38)}$, it needs to be emphasised that when using the GreenFeed system, $3 \mathrm{~d}$ of spot sampled $\mathrm{CH}_{4}$ measurements are insufficient to accurately reflect an animal's daily $\mathrm{CH}_{4}$ exhal rate. Further, one has to consider $\mathrm{CH}_{4}$ losses via the fistula. However, for the purpose of this study, the spot measures were simply an indication of the $\mathrm{CH}_{4}$ emitted by each animal for a set time point across treatments at set times of the day. Corroboration of our results using respiration chambers would be welcome.

Gas insufflation has previously led to an increase in rumen contractions in various studies ${ }^{(55)}$, but its effect has typically been investigated by enforcing an increase in intra-ruminal pressure by blocking eructation for a certain period of time. Eructation was prevented in a cow and different insufflation treatments of air, $\mathrm{CH}_{4}$ or $\mathrm{H}_{2}$ had no apparent effects on rumen contraction $^{(56)}$. Another study did not detect a difference in rumen motility between insufflations of $\mathrm{CO}_{2}: \mathrm{O}_{2}(5: 95), \mathrm{CO}_{2}: \mathrm{N}_{2}$ (5:95) or $\mathrm{CO}_{2}: \mathrm{CH}_{4}(60: 40)$ mixtures in decerebrated sheep ${ }^{(57)}$. Intra-ruminal pressure was increased in sheep by blocking the trachea, and gases containing $\mathrm{CO}_{2}$ (i.e., both exhaled air and a $\mathrm{CO}_{2}: \mathrm{CH}_{4}$ (60:40) mixture) stimulated more primary rumen contractions during the pressure-release phase than $\mathrm{N}_{2}$ or compressed air ${ }^{(55)}$. In bison (whose eructations were not impeded), an increase in secondary rumen contractions from 0.5 to $1.0 / \mathrm{min}$ was observed when $\mathrm{N}_{2}$ was insufflated at a rate of $3-5$ litre/ $\mathrm{min}^{(58)}$. In the animals of the present study, eructations were not impeded, and the insufflation rate was about $200 \mathrm{ml} / \mathrm{min}$. Therefore, the effect of insufflation alone due to physical distension of the RR can be considered less relevant. $\mathrm{H}_{2}$ insufflation at $800 \mathrm{ml} / \mathrm{min}$ did not affect feed intake in cattle $^{(54)}$. To our knowledge, no studies on the effect of insufflation on MRT or whole-tract digestibility in ruminants exist.

\section{Bromochloromethane treatment}

A number of previous studies have demonstrated the $\mathrm{CH}_{4}$ suppressing effect of BCM in steers, sheep and goats ${ }^{(31,59-64)}$. The present study confirms again, in non-lactating dairy cattle, that BCM substantially reduces $\mathrm{CH}_{4}$ exhal. For the present study, this treatment efficiently created conditions of low $\mathrm{CH}_{4}$ production. The previous studies mentioned above produced different results with respect to the DMI-reducing effect of BCM. No reduction in DMI was reported for steers fed diets high in concentrates $^{(31,60)}$ or sheep and goats fed diets of hay and concentrate ${ }^{(59,61,62)}$. In contrast, there was a reduction in DMI for steers fed both low-quality and medium-quality roughage diets $^{(64)}$, similar to the situation with the low-quality roughage fed in the present study. As average daily BM gain did not differ in the steers, this corresponded to a higher feed conversion ratio $^{(64)}$. In the present study, BM losses were concomitantly lowest on this treatment, possibly due to the increase in ME content of the diet owing to the massively reduced $\mathrm{CH}_{4}$ loss. In saying this, a complete understanding of the mechanism needs to be achieved. This includes investigation of other potential effects of BMC such as an increased proportion of propionate produced by microbial fermentation or increased nutrient 
availability. In another study ${ }^{(59)}$, such an increase in ME content was also considered responsible for higher milk yield in BCM-treated goats, and similar effects were observed with other $\mathrm{CH}_{4}$ inhibitors ${ }^{(65)}$

\section{Variability of DM intake}

The variation in DMI measured in our study represents a constraint on its interpretation, because all aspects of digestive physiology are known to be influenced by feed intake, particularly measures of $\mathrm{MRT}^{(66)}$, rumen motility and rumination activity $^{(67)}$. Despite efforts to minimise variation in intake, DMI varied in our study, both between cows and periods, and cows had lower intakes on the BCM treatment. Ruminants produce less $\mathrm{CH}_{4}$ on concentrate-dominated diets ${ }^{(68,69)}$, and hence any ME-sparing effects of BCM should be less pronounced on such diets, leading to less distinct differences in intake. Therefore, feeding the cows a concentrate-based diet in the present study would probably have resulted in less overall variation in both DMI and $\mathrm{CH}_{4}$ reduction, and hence might not have necessarily resulted in a clearer signal. Evidently, hay of better quality should have been used for the current study. The combined effect of both the level of DMI and the presence of $\mathrm{CH}_{4}$ translates into significant effects of treatment on many of the physiological variables measured when $\mathrm{rDMI}$ is included as a covariable in the analysis but no direct difference between treatments in pairwise comparisons that do not account for rDMI (Table 2).

\section{Effects on digestive physiology}

The $\mathrm{CH}_{4} \mathrm{RRf}$ was only significantly affected by the BCM treatment. As far as we are aware, this is the first report in the literature of an effect of $\mathrm{BCM}$ on rumen fluid $\mathrm{CH}_{4}$ concentration, and the magnitude of the effect ( $99 \%$ reduction) is notable. For several measures of MRT in the GIT, total tract digestibility and faecal DM concentration, the BCM treatment produced outstanding numerical differences to the other treatments. The $\mathrm{iCH}_{4}$ treatment did not represent the opposing extreme (Table 2), and this might suggest that relevant physiological effects are mainly linked to dissolved $\mathrm{CH}_{4}$ and not the $\mathrm{CH}_{4}$ concentration in rumen gas that is eructated. Dissolved $\mathrm{CH}_{4}$ might act on receptors directly located in the digestive tract or after absorption into portal blood ${ }^{(39)}$ and distribution in the body. In particular, dissolved $\mathrm{CH}_{4}$ may pass into the lower digestive tract causing a change in its motility similar to that found in guinea pigs ${ }^{(22,23)}$. Gaseous $\mathrm{CH}_{4}$ cannot be expected to reach those sites (but may be produced in lower amounts in the large intestine). Whether the effects suggested in the present study are really triggered by $\mathrm{CH}_{4}$, or by some other factor associated with our treatments, for example, changes in dissolved $\mathrm{H}_{2}$, remains to be clarified.

The $\mathrm{iCH}_{4}$ treatment affected rumen motility and rumination activity in the opposite direction to BCM treatment (Table 2). Notably, exhaled $\mathrm{CH}_{4}$ yield, but not $\mathrm{CH}_{4}$ in rumen fluid, was significantly correlated with $\mathrm{MRT}_{\text {particle }} \mathrm{RR}$ (Table 3). Although gaseous $\mathrm{CH}_{4}$ is most likely not absorbed in the GIT, gassing GIT segments with $\mathrm{CH}_{4}$ in vitro has led to the changes in peristalsis described in the introduction ${ }^{(22,23)}$. In addition, because a large proportion of the gas eructated from the rumen is inhaled into the lungs and then exhaled ${ }^{(70)}$, some $\mathrm{CH}_{4}$ can be recovered in the arterial blood flow from the lungs ${ }^{(39,71)}$ and can be distributed throughout the body in this way.

The findings of the present study suggest that dissolved and, possibly to a lesser extent, also gaseous $\mathrm{CH}_{4}$ had an effect on the digestive physiology of the cows. The effect was consistent across the various measures, whereby decreased $\mathrm{CH}_{4}$ was associated with (i) a decrease in rumen motility with a concomitant increase in rumination time and intensity, (ii) a longer MRT in the RR but mainly in the lower digestive tract (with concomitantly drier faeces) and (iii) an increased apparent digestibility of fibre and $\mathrm{CP}$. In other words, less $\mathrm{CH}_{4}$ was associated with reduced motility, increased MRT and increased fibre and $\mathrm{CP}$ digestibility. A similar effect of another $\mathrm{CH}_{4}$ inhibitor on digestibility was documented in an experiment where there was no confounding between treatment groups from variation in $\mathrm{DMI}^{(65)}$.

These findings were unexpected, given the general association of increased exhaled $\mathrm{CH}_{4}$ yield with longer digesta retention within and across various species including man as outlined in the introduction. However, the findings could be tentatively interpreted as an indication of a feedback mechanism, by which ruminants attempt to counteract the loss of ingested energy to $\mathrm{CH}_{4}$, or using $\mathrm{CH}_{4}$ production to adjust digestive physiology. In such a feedback system, the high $\mathrm{CH}_{4}$ levels could signal successful fermentation of plant fibre, and hence trigger digesta propulsion, whereas low $\mathrm{CH}_{4}$ levels could signal that fermentation has not yet occurred to a favourable extent, and hence delay of propulsion is indicated. Such a system would represent a fine-tuning of events that are otherwise mainly dominated by the level of feed intake, which controls digesta retention, digestion, and hence $\mathrm{CH}_{4}$ production $^{(9)}$. Such a hypothetical mechanism would also match the expectation that, over evolutionary time, some adaptations should evolve to counter the seemingly inevitable energetic losses due to the omnipresence of methanogens.

Experimental evidence on the effect of $\mathrm{CH}_{4}$ on gut motility in monogastric animals is, however, typically interpreted in the opposite direction: $\mathrm{CH}_{4}$ is assumed to delay digesta transit by increasing the amplitude of peristaltic contractions in and by decreasing their velocity of travel along the small intestinal segments in in vitro assays in guinea pig intestine ${ }^{(22,23)}$. However, extra $\mathrm{CH}_{4}$ did not change the rate at which an artificial digesta bolus was transported in the proximal or distal colon in such a setting ${ }^{(23)}$. Another experimental approach consisted of measuring the recovery of a marker applied to a $150-\mathrm{cm}$ small intestinal segment of fistulated dogs at a second, more distal fistula during a time period of $30 \mathrm{~min}$, during which $2 \mathrm{ml}$ of buffer was infused per minute (a total of $60 \mathrm{ml}$ ); recovery of the marker was apparently not calculated using the marker concentration in the total recovered amount of fluid, but from six 1-ml samples collected at 5-min intervals ${ }^{(22)}$. With this method, calculated marker recovery was reduced when the subsequent segment of the intestine was insufflated with $\mathrm{CH}_{4}$. More experimental evidence for modulation of gut motility by $\mathrm{CH}_{4}$ is warranted.

Whether, in man, higher enteric $\mathrm{CH}_{4}$ levels are a cause or an effect of prolonged colonic retention times (and hence 
constipation-related disorders) remains controversial. Limited clinical trials with the application of antibiotics that primarily target methanogens led to a reduction in constipation-related symptoms ${ }^{(24,72)}$. However, it was pointed out that the reduction in breath $\mathrm{CH}_{4}$ did not exactly match the reduction in clinical symptoms ${ }^{(73)}$. In these studies, colonic digesta passage was not quantified. However, interventions that specifically targeted digesta retention both behaviourally and/or pharmacologically and/or even included the application of dietary fibre (a substrate for methanogenesis) not only led to a reduction in digesta retention but also in $\mathrm{CH}_{4}$ production ${ }^{(18,74,75)}$. Whether colonic motility and retention can be influenced in a clinical setting by specifically changing $\mathrm{CH}_{4}$ production only or whether $\mathrm{CH}_{4}$ exhal indicates changes in motility and retention achieved by other effects remains to be investigated.

The only existing evidence known to us for an effect of $\mathrm{CH}_{4}$ level on digesta retention in ruminants found both lower $\mathrm{CH}_{4}$ yields and shorter $\mathrm{MRT}_{\text {fluid }} \mathrm{RR}$ in sheep supplemented with nitrate as compared with a control group ${ }^{(25)}$; however, as the study design did not include a cross-over or a record of baseline values, it remains an open question whether decreased MRT represented an effect of reduced $\mathrm{CH}_{4}$ or the natural variation in MRT and $\mathrm{CH}_{4}$ in sheep ${ }^{(10)}$ with an independent effect on $\mathrm{CH}_{4}$ in the treatment group.

Thus, in conclusion, the present study opens the possibility that $\mathrm{CH}_{4}$ production in ruminants is not only affected by levels of food intake, digesta retention, diet composition or other anatomical or physiological traits influencing digestive physiology, but that the level of $\mathrm{CH}_{4}$ production itself could influence some of these processes in the sense of a feedback mechanism. These results raise questions about the exact feedback mechanisms (e.g., $\mathrm{CH}_{4}$ receptors), and represent an interesting contribution to the basic knowledge about ruminant and potentially general herbivore digestive physiology. For future studies, a constant food intake across treatments as well as the addition of dissolved $\mathrm{CH}_{4}$ to both the digestive tract and the vascular system would be desirable.

\section{Acknowledgements}

We thank Keith Bamford, Debby Cockman, Colin Green, Andy Hicks and Anna Thompson from CEDAR for their support during the experiments. The authors are grateful to Nigel Tomkins for sharing his experience in BCM usage, to Heidrun Barleben for the analysis of numerous retention time samples, to Gerhard Breves and Klaus-Werner Grunert for their support with the rumen motility measurements, to Neil Donovan for the analysis of $\mathrm{CH}_{4}$ in rumen fluid, to Joel Niederhauser and Nils Zehner for their support with the RumiWatch measurements and to two anonymous reviewers for their comments that greatly improved the manuscript.

This study was a part of the project 310030_135252/1 funded by the Swiss National Science Foundation (SNF). The SNF had no role in the design, analysis and writing of this article.

M. C., M. K., K.-H. S., C. K. R., D. J. H. and L. A. C. designed the study; M. T. D., K. J. H., P. K., D. J. H., L. A. C. and M. C. performed the study; L. A. C., S. O., T. H. M., K.-H. S., A. S., M. K. contributed analytical tools; M. T. D., K. J. H. and M. C. analysed the data; M. T. D., K. J. H. and M. C. drafted the first version of the manuscript; all authors contributed to further versions and approved the final version of the manuscript.

The authors declare that there are no conflicts of interest.

\section{References}

1. Johnson KA \& Johnson DE (1995) Methane emission from cattle. J Anim Sci 73, 2483-2492.

2. Intergovernmental Panel on Climate Change (2013) Fifth assessment report (AR5). https://www.ipcc.ch/report/ar5 (accessed January 2016)

3. Moss AR, Jouany JP \& Newbold J (2000) Methane production by ruminants: its contribution to global warming. Ann Zootech 49, 231-253.

4. Joblin KN (1999) Ruminal acetogens and their potential to lower ruminant methane emissions. Crop Pasture Sci 50 , $1307-1314$

5. Russell JB (1998) The importance of $\mathrm{pH}$ in the regulation of ruminal acetate to propionate ratio and methane production in vitro. J Dairy Sci 81, 3222-3230.

6. Pinares-Patiño CS, Ulyatt MJ, Lassey KR, et al. (2003) Rumen function and digestion parameters associated with differences between sheep in methane emissions when fed chaffed lucerne hay. J Agric Sci 140, 205-214.

7. Barnett MC, Goopy JP, McFarlane JR, et al. (2012) Triiodothyronine influences digesta kinetics and methane yield in sheep. Anim Prod Sci 52, 572-577.

8. Barnett MC, McFarlane JR \& Hegarty RS (2014) Low ambient temperature elevates plasma triiodothyronine concentrations while reducing digesta mean retention time and methane yield in sheep. J Anim Physiol Anim Nutr 99, 483-491.

9. Hammond KJ, Pacheco D, Burke JL, et al. (2014) The effects of fresh forages and feed intake level on digesta kinetics and enteric methane emissions from sheep. Anim Feed Sci Technol 193, 32-43.

10. Goopy JP, Donaldson A, Hegarty R, et al. (2014) Low-methane yield sheep have smaller rumens and shorter rumen retention time. BrJ Nutr 111, 578-585.

11. Frei S, Hatt J-M, Ortmann S, et al. (2015) Comparative methane emission by ratites: differences in food intake and digesta retention level out methane production. Comp Biochem Physiol A 188, 70-75.

12. Vendl C, Frei S, Dittmann MT, et al. (2016) Methane production by two non-ruminant foregut-fermenting herbivores: the collared peccary (Pecari tajacu) and the pygmy hippopotamus (Hexaprotodon liberiensis). Comp Biochem Physiol A 191, 107-114.

13. Vendl C, Frei S, Dittmann MT, et al. (2016) Digestive physiology, metabolism and methane production of captive Linné's two-toed sloths (Choloepus didactylus). J Anim Physiol Anim Nutr 100, 552-564.

14. Janssen PH (2010) Influence of hydrogen on rumen methane formation and fermentation balances through microbial growth kinetics and fermentation thermodynamics. Anim Feed Sci Technol 160, 1-22.

15. Huhtanen P, Ramin M \& Cabezas-Garcia E (2016) The effects of ruminal digesta retention time on methane emissions a modelling approach. Anim Prod Sci 56, 501-506.

16. Okine EK, Mathison GW \& Hardin RT (1989) Effects of changes in frequency of reticular contractions on fluid and particulate passage rates in cattle. J Anim Sci 67, 3388-3396.

17. Attaluri A, Jackson M, Valestin J, et al. (2010) Methanogenic flora is associated with altered colonic transit but not stool characteristics in constipation without IBS. Am J Gastroenterol 105, 1407-1411.

18. Soares ACF, Lederman HM, Fagundes-Neto U, et al. (2005) Breath methane associated with slow colonic transit time in 
children with chronic constipation. I Clin Gastroenterol 39 , 512-515.

19. Chatterjee S, Park S, Low K, et al. (2007) The degree of breath methane production in IBS correlates with the severity of constipation. Am J Gastroenterol 102, 837-841.

20. Kunkel D, Basseri RJ, Makhani MD, et al. (2011) Methane on breath testing is associated with constipation: a systematic review and meta-analysis. Dig Dis Sci 56, 1612-1618.

21. Di Stefano M, Mengoli C, Bergonzi M, et al. (2015) Breath methane excretion is not an accurate marker of colonic methane production in irritable bowel syndrome. $A m J$ Gastroenterol 110, 891-898.

22. Pimentel M, Lin HC, Enayati P, et al. (2006) Methane, a gas produced by enteric bacteria, slows intestinal transit and augments small intestinal contractile activity. Am J Physiol 290, G1089-G1095.

23. Jahng J, Jung IS, Choi EJ, et al. (2012) The effects of methane and hydrogen gases produced by enteric bacteria on ileal motility and colonic transit time. Neurogastroenterol Motil 24, 185-192.

24. Pimentel M, Chatterjee S, Chow EJ, et al. (2006) Neomycin improves constipation-predominant irritable bowel syndrome in a fashion that is dependent on the presence of methane gas: subanalysis of a double-blind randomized controlled study. Dig Dis Sci 51, 1297-1301.

25. Nolan JV, Hegarty RS, Hegarty J, et al. (2010) Effects of dietary nitrate on fermentation, methane production and digesta kinetics in sheep. Anim Prod Sci 50, 801-806.

26. Knight T, Ronimus RS, Dey D, et al. (2011) Chloroform decreases rumen methanogenesis and methanogen populations without altering rumen function in cattle. Anim Feed Sci Technol 166, 101-112.

27. Hammond KJ, Humphries DJ, Crompton LA, et al. (2015) Methane emissions from cattle: estimates from short-term measurements using a GreenFeed system compared with measurements obtained using respiration chambers or sulphur hexafluoride tracer. Anim Feed Sci Technol 203, 41-52.

28. National Research Council (2001) Nutrient Requirements of Dairy Cattle. Washington, DC: National Academies Press.

29. Thomas C (2007) Feed into Milk: A New Applied Feeding System for Dairy Cows. Nottingham, UK: Nottingham University Press.

30. Hammond KJ, Humphries DJ, Crompton LA, et al. (2014) Methane emissions from lactating and dry dairy cows fed diets differing in forage source and NDF concentration. ADSAASAS-CSAS Joint Annual Meeting, Kansas City, MO, USA, abstract 643. 20-24 July 2014.

31. Tomkins NW, Colegate SM \& Hunter RA (2009) A bromochloromethane formulation reduces enteric methanogenesis in cattle fed grain-based diets. Anim Prod Sci 49, 1053-1058.

32. May C, Payne AL, Stewart PL, et al. (1995) A delivery system for agents. International patent application no. PCT/AU95/ 00733 .

33. Menke KH, Raab L, Salewski A, et al. (1979) The estimation of the digestibility and metabolizable energy content of ruminant feedingstuffs from the gas production when they are incubated with rumen liquor in vitro. J Agric Sci 93, 217-222.

34. Reynolds CK, Humphries DJ, Kirton P, et al. (2014) Effects of 3-nitrooxypropanol on methane emission, digestion, and energy and nitrogen balance of lactating dairy cows. J Dairy Sci $97,3777-3789$

35. Udén P, Colucci PE \& Van Soest PJ (1980) Investigation of chromium, cerium and cobalt as markers in digesta. Rate of passage studies. J Sci Food Agric 31, 625-632.

36. Schwarm A, Ortmann S, Wolf C, et al. (2009) No distinct difference in the excretion of large particles of varying size in a wild ruminant, the banteng (Bos javanicus). Eur I Wildl Res 55, 531-533.

37. Zehner N, Niederhauser JJ, Nydegger F, et al. (2012) Validation of a new health monitoring system (RumiWatch) for combined automatic measurement of rumination, feed intake, water intake and locomotion in dairy cows. Proceedings of the International Conference of Agricultural Engineering CIGR-Ageng, C0438. 8-12 July 2012.

38. Hammond KJ, Waghorn GC \& Hegarty RS (2016) The GreenFeed system for measurement of enteric methane emission from cattle. Anim Prod Sci 56, 181-189.

39. Reynolds CK, Crompton LA, Barratt CB, et al. (2013) Arterial, rumen and milk concentration and net absorption of methane into the portal vein of lactating dairy cattle. Adv Anim Biosci 4, 392 .

40. Association of Official Analytical Chemists (2012) Official Methods of Analysis of AOAC International. Gaithersburg, MD: AOAC International.

41. Frei S, Ortmann S, Reutlinger C, et al. (2015) Comparative digesta retention patterns in ratites. Auk Ornithol Adv 132, 119-131.

42. Shipley RA \& Clark RE (1972) Tracer Methods for In Vivo Kinetics. New York, NY: Academic Press.

43. Dhanoa MS, Siddons RC, France J, et al. (1985) A multicompartmental model to describe marker excretion patterns in ruminant faeces. Br J Nutr 53, 663-671.

44. Bruining M \& Bosch MW (1992) Ruminal passage rate as affected by CrNDF particle size. Anim Feed Sci Technol 37, 193-200.

45. Hackmann TJ \& Spain JN (2010) Ruminant ecology and evolution: perspectives useful to ruminant livestock research and production. J Dairy Sci 93, 1320-1334.

46. Müller DWH, Codron D, Meloro C, et al. (2013) Assessing the Jarman-Bell principle: scaling of intake, digestibility, retention time and gut fill with body mass in mammalian herbivores. Comp Biochem Physiol A 164, 129-140.

47. Clauss M, Steuer P, Erlinghagen-Lückerath K, et al. (2015) Faecal particle size: digestive physiology meets herbivore diversity. Comp Biochem Physiol A 179, 182-191.

48. $\mathrm{R}$ Development Core Team (2012) $R$ : A Language and Environment for Statistical Computing. Vienna, Austria: R Foundation for Statistical Computing.

49. Lechner I, Barboza P, Collins W, et al. (2010) Differential passage of fluids and different-sized particles in fistulated oxen (Bos primigenius f. taurus), muskoxen (Ovibos moschatus), reindeer (Rangifer tarandus) and moose (Alces alces): rumen particle size discrimination is independent from contents stratification. Comp Biochem Physiol A 155, 211-222.

50. Dittmann MT, Runge U, Ortmann S, et al. (2015) Digesta retention patterns of solute and different-sized particles in camelids compared with ruminants and other foregut fermenters. J Comp Physiol B 185, 559-573.

51. Schwarm A, Albrecht S, Ortmann S, et al. (2011) Digesta retention time in roe deer (Capreolus capreolus) as measured with cerium-, lanthanum-, and chromium-mordanted fibre. Eur J Wildl Res 57, 437-442.

52. Davidovich A, Bartley EE, Bechtle RM, et al. (1977) Ammonia toxicity in cattle. III. Absorption of ammonia gas from the rumen and passage of urea and ammonia from the rumen to the duodenum. J Anim Sci 45, 551-558.

53. Murray RM, Bryant MP \& Leng RA (1976) Rates of production of methane in the rumen and large intestine of sheep. $\mathrm{Br} \mathrm{J}$ Nutr 36, 1-14.

54. Olijhoek DW, Hellwing ALF, Weisbjerg MR, et al. (2016) Effect of short-term infusion of hydrogen on enteric gas production and rumen environment in dairy cows. Anim Prod Sci 56, 466-471. 
55. Louvier JA, Colvin HW, Ishizaki G, et al. (1979) Effect of rumen insufflation on ruminal contraction rate in sheep. J Anim Sci 48, 934-940.

56. Dougherty RW (1940) Physiological studies of induced and natural bloat in dairy cattle. JAVMA 96, 43-46.

57. Reid CS \& Titchen DA (1965) Reflex stimulation of movements of the rumen in decerebrate sheep. J Physiol 181, 432-448.

58. Dziuk HE (1965) Eructation, regurgitation, and reticuloruminal contraction in the American bison. Am J Physiol 208, 343-346.

59. Abecia L, Toral PG, Martín-García AI, et al. (2012) Effect of bromochloromethane on methane emission, rumen fermentation pattern, milk yield, and fatty acid profile in lactating dairy goats. J Dairy Sci 95, 2027-2036.

60. Johnson ED, Wood AS, Stone JB, et al. (1972) Some effects of methane inhibition in ruminants (steers). Can J Anim Sci 52, 703-712.

61. Sawyer MS, Hoover WH \& Sniffen CJ (1974) Effects of a ruminal methane inhibitor on growth and energy metabolism in the ovine. J Anim Sci 38, 908-914.

62. Lalu K, Bhar R, Das A, et al. (2009) Effect of bromochloromethane supplementation and dietary energy restriction on methane production and efficiency of energy utilization in rams. Indian J Anim Nutr 26, 97-102.

63. Mitsumori M, Shinkai T, Takenaka A, et al. (2012) Responses in digestion, rumen fermentation and microbial populations to inhibition of methane formation by a halogenated methane analogue. Br J Nutr 108, 482-491.

64. McCrabb GJ, Berger KT, Magner T, et al. (1997) Inhibiting methane production in Brahman cattle by dietary supplementation with a novel compound and the effects on growth. Austr J Agric Res 48, 323-329.

65. Hristov AN, Oh J, Giallongo F, et al. (2015) An inhibitor persistently decreased enteric methane emission from dairy cows with no negative effect on milk production. Proc Natl Acad Sci U S A 112, 10663-10668.

66. Clauss M, Streich WJ, Schwarm A, et al. (2007) The relationship of food intake and ingesta passage predicts feeding ecology in two different megaherbivore groups. Oikos 116, 209-216.

67. Deswysen AG, Ellis WC \& Pond KR (1987) Interrelationships among voluntary intake, eating and ruminating behavior and ruminal motility of heifers fed corn silage. J Anim Sci 64 , 835-841.

68. Beauchemin K, Kreuzer M, O'Mara F, et al. (2008) Nutritional management for enteric methane abatement: a review. Aust J Exp Agric 48, 21-27.

69. Hristov AN, Oh J, Firkins JL, et al. (2013) Mitigation of methane and nitrous oxide emissions from animal operations: I. A review of enteric methane mitigation options. J Anim Sci 91, 5045-5069.

70. Dougherty RW (1968) Eructation in ruminants. Ann N Y Acad Sci 150, 22-26.

71. Dougherty RW, Allison MJ \& Mullenax CH (1964) Physiological disposition of $\mathrm{C}^{14}$-labeled rumen gases in sheep and goats. Am J Physiol 207, 1181-1188.

72. Pimentel M, Chang C, Chua KS, et al. (2014) Antibiotic treatment of constipation-predominant irritable bowel syndrome. Dig Dis Sci 59, 1278-1285.

73. Sachdeva S, Kondala R, Dahale AS, et al. (2014) Antibiotic treatment of constipation-predominant irritable bowel syndrome: the puzzle is yet to be solved. Dig Dis Sci 59, 2836-2837.

74. El Oufir L, Flourié B, Bruley des Varannes S, et al. (1996) Relations between transit time, fermentation products, and hydrogen consuming flora in healthy humans. Gut 38, 870-877.

75. Vega AB, Perelló A, Martos L, et al. (2015) Breath methane in functional constipation: response to treatment with Ispaghula husk. Neurogastroenterol Motil 27, 945-953. 